\author{
Anna Hernandez-Poeczyńska
}

\title{
Immigration Problems Facing the European Union from the Perspective of UN Human Rights Council Mechanisms
}

\begin{abstract}
Introduction
The European Union (EU) Member States are the main destination for the constantly rising number of migrants from Asia and Africa. Irregular migrants who try to enter the EU territory often put their lives at risk and are exposed to serious human rights violations. The 2015 migration crisis highlighted the urgent need to reform the EU policy framework. One year later, the problem still remains unresolved.

The topic of immigration and the many problems the EU faces in this regard is complex and can therefore not be presented comprehensively, in all its aspects. Thus, the aim of this article is to analyse how this issue is reflected in two UN Human Rights Council's mechanisms: the Special Procedures and the Universal Periodic Review (UPR). This approach allows the independent assessment of the EU's activities related to migration made by the Special Rapporteur on migrants to be confronted with the recommendations taken up in the UPR of EU Member States. The subject of the analysis will be the thematic and country reports prepared by the Special Rapporteur on migrants and the UPR recommendations addressed to three countries visited by the Special Rapporteur: Italy, Greece and Malta.
\end{abstract}

\section{The Special Rapporteur's Study on the Management of the External Borders of the EU}

The Special Procedures of the Human Rights Council consist of country and thematic mandates established to address human rights issues. Mandate holders exercise their functions as Special Rapporteurs, Independent Experts or members of Working Groups. One of the most important activities of Special Procedures is carrying out country visits and presenting annual reports to the Human Rights Council. Both of them were used 
by the Special Rapporteur on the human rights of migrants, François Crépeau, who decided to focus on the management of the external borders of the European Union and its impact on the human rights of migrants in the first year of his mandate. For this reason, he made visits to Greece ${ }^{1}$, Italy ${ }^{2}$, Tunisia and Turkey in 2012 and prepared the annual report ${ }^{3}$ which includes the results and recommendations of the one-year study submitted to the Human Rights Council in April 2013. The follow-up to this study was conducted two years later and its conclusions were also presented in the last Special Rapporteur's annual report "Banking on mobility over a generation" ${ }^{4}$ In December 2014, the Special Rapporteur visited Italy ${ }^{5}$ (the follow-up mission) and Malta ${ }^{6}$.

The underlying message of the two thematic reports is the necessity of changing the focus of migration policy from a security-based approach to human rights-based one. The analysis outlines the elements of the migration system which affect the rights of migrants, although it does not invoke examples of concrete violations. Reports of country missions submitted as the addenda to the annual reports contain more specific remarks and recommendations, however, they share the same diagnosis of the situation. The follow-up report, prepared during the escalation of immigration problems in Europe is more detailed and contains more concrete recommendations. It underlies the need for far-reaching changes in the EU's approach towards migration as the increase of migrants arriving in Europe is inevitable.

The Special Rapporteur identified numerous problems related to the impact of the management of the EU borders on the rights of migrants. In general, the guarantee of these rights is assessed as not being adequate, especially with regard to the situation of irregular migrants. The regulations of the migration system prioritize security over the rights of migrants and focus on the eradication of irregular migration, often by ensuring the quickest possible return to the country of origin or the first entry. The lack of the human rights-based approach is noticed even more in practice. The implementation of this approach, which "remains largely absent", was also recommended to Italy, Greece and Malta in the country missions reports.

One of the main concerns of the Special Rapporteur is the process of the externalization of border control. The responsibility of preventing irregular migration is transmitted outside the EU to the countries of departure or transit mainly by readmission

1 The mission report: A/HRC/23/46/Add.4.

2 The mission report : A/HRC/23/46/Add.3.

$3 \mathrm{~A} / \mathrm{HRC} / 23 / 46$.

$4 \mathrm{~A} / \mathrm{HRC} / 29 / 36$.

5 The mission report: A/HRC/29/36/Add.2.

6 The mission report: A/HRC/29/36/Add.3.

$7 \mathrm{~A} / \mathrm{HRC} / 23 / 46, \S 36$. 
agreements and mobility partnerships ${ }^{8}$. These tools are criticized for their insufficient guarantees of the rights of migrants. In the 2013 report the capacity-building of foreign agents operating in border control was also indicated as a way of promoting externalization. In this regard, the negative assessment of the Special Rapporteur casts doubt, since it is difficult to condemn the assistance offered to non-EU countries. However, the Special Rapporteur seems to perceive the whole process of externalization as replacing the practices of push-backs challenged by the European Court of Human Rights in Hirsi Jamaa and Others v. Italy and allowing the EU "to wash its hands of its responsibility to guarantee the human rights of those persons attempting to reach its territory" ${ }^{\text {. One of }}$ the recommendations taken up by the Special Rapporteur in this regard is to monitor the protection of human rights of returnees as has been done in Pakistan and Ukraine since 2014, when a pilot project of the European Commission was started. The problem of externalization was also noticed in the country mission reports. In the case of Italy, returning migrants to Libyan shores against their will and "quick return" agreements with Tunisia and Egypt were invoked.

Another problem identified in the Special Rapporteur's study is the use of detention as a regular tool in border control. Moreover, detention is often applied to migrants without prospects of removal, prolonged and not decided on a case-by-case basis. It contravenes the requirements of the international human rights law according to which the detention must be prescribed by law, necessary, reasonable and proportional to its objectives and the regulations of the Return Directive ${ }^{10}$. This was stressed in particular in the Greece report. Greece was reminded that detention should be a measure of the last resort and it was recommended that the policy of systematic detention of all irregular migrants should be ended.

The inadequate conditions of detention are emphasized as well, including the militaristic or prison-like style of the detention centres, insufficient health care, lack of access to proper legal aid and consular and interpretation services, lack of recourse to effective remedies, and lack of a proper system of guardianship for children. Not only are the EU and its Member States reluctant to explore alternatives to detention themselves, but they also encourage and financially support the creation of the detention centres in neighbouring states, e.g. in Turkey and Albania. Detention problems are also tackled in the country mission reports. Some of the recommendations concern more specific

8 Special Rapporteur invokes both the examples of readmission agreements signed by the EU (e.g. with Turkey) and EU Member States (e.g. Italy-Egypt or Greece-Turkey. As for the mobility partnerships, four them are mentioned in the 2015 report, i.e. with Azerbaijan, Jordan, Morocco and Tunisia.

$9 \mathrm{~A} / \mathrm{HRC} / 23 / 46, \S 58$.

10 Directive 2008/115/EC of the European Parliament and of the Council of 16 December 2008 on common standards and procedures in Member States for returning illegally staying thirdcountry nationals, Chapter IV. 
issues, such as informing detainees in a language they understand of the reason for and duration of the detention and their rights, training programs for people working in the detention centers (Greece, Malta, Italy - both reports), reduction of the maximum period of detention for the purposes of identification to 6 months (Italy - 2013 report), establishing a fairer and simpler system for migrant detainees to challenge expulsion and detention orders (Italy - 2015 report).

It is worth mentioning that some burning issues discussed in Europe today were tackled in the 2013 report, which proves that the EU and its Member States have not managed to resolve the problems in spite of being notified about them. First of all, the burden of dealing with the migration crisis continues to rest on Member States situated at the external border. In relation to this, the Special Rapporteur criticized the provision of the Dublin II Regulation ${ }^{11}$ which stated that asylum claimants can only apply for asylum in the country of their first entry to the EU ${ }^{12}$. This forced many people to continue their journeys, often in precarious conditions, without assurance that without trying to change their irregular status. Secondly, the difficulties with rescuing people in distress on boats noted in the 2013 report are still present. In this regard, the Special Rapporteur emphasized the lack of cooperation by States with private entities. Thirdly, the EU's migration policy is shaped by Member States that have been influenced by an increasingly anti-immigrant public opinion, which has even become worse in the past two years.

In the Greek report, the Special Rapporteur drew attention to the discriminatory attitudes of society which should be counteracted by the state. It was recommended that Greece should inter alia investigate all cases of xenophobic violence and attacks against migrants, initiate strong public discourse on social diversity and inclusion, conduct public campaigns on racism and xenophobia, and include human rights education and awareness-raising in the educational curriculum of public schools.

The EU is also advised to acknowledge and address the "push" and "pull" factors of immigration. In the 2015 report, it was suggested that the EU and its Member States "take a global leadership role in relation to the Syrian civil war and other humanitarian crises"13. As for the "pull factors", the EU should address the demand for a seasonal and low-skilled workforce opening up legal ways to enter its territory.

After the issuance of the 2013 report, the immigration problems in Europe have escalated and the management of the EU external border has not changed in line with its recommendations. For this reason, the follow-up report contains similar conclusions to

11 Council Regulation (EC) No 343/2003 of 18 February 2003 establishing the criteria and mechanisms for determining the Member State responsible for examining an asylum application lodged in one of the Member States by a third-country national, Official Journal L 050, 25/02/2003 P. $0001-0010$.

12 In Dublin III Regulation (No 604/2013 of 26 June 2013, Official Journal L 180/3 , 29/06/2013) which replaced Dublin II this provision was repeated, however, its application was suspended by Germany and Czech Republic in August/September 2015.

$13 \mathrm{~A} / \mathrm{HRC} / 29 / 36 ., \S 100$. 
the previous one, while also stressing the impossibility of "sealing" the borders and the inevitability of the increase in immigration. The EU and its Member States are advised to develop a 25-year strategy with short-, medium- and long-term interventions, taking into consideration the demographic and labour market changes that Europe will face in this period of time.

To sum up the conclusions of the Special Rapporteur's study, the human rights-based framework of migration policy proposed by him should be presented. The elements of this framework are the following: increasing search and rescue capacity, facilitating access to justice, developing alternatives to detention, reinforcing labour inspections mechanisms to guarantee the rights of migrant workers, creating resettlement programmes for refugees, and multiple labour migration visa opportunities ${ }^{14}$.

The press release issued last year by the Special Rapporteur confirmed the obvious diagnosis - the EU and its Member States had not managed to implement the suggested framework and ensure adequate respect for migrants rights. On 25 August 2015, François Crépeau again called on the European Union to establish a human rightsbased migration policy. He expressed his disbelief in the effectiveness of the EU activities in the words: "Let's not pretend that what the EU and its member states are doing is working. Migration is here to stay. Building fences, using tear gas and other forms of violence against migrants and asylum seekers, detention, withholding access to basics such as shelter, food or water and using threatening language or hateful speech will not stop migrants from coming or trying to come to Europe."15 The Special Rapporteur encouraged the EU to offer more regular ways to enter its territory and to create a massive resettlement programme for refugees like the Syrians and Eritreans. He also welcomed the positive steps in rescuing migrants and asylum seekers at sea.

\section{The Universal Periodic Review Recommendations on Migrants and Refugees}

The Universal Periodic Review (UPR) is a cooperative mechanism which allows all states to address questions, statements and recommendations concerning the fulfillment by each UN Member of its human rights obligations and commitments. The first cycle of the UPR started in 2008 and ended in 2011. The second cycle will be completed in 2016.

The peer review is based on a national report prepared by the state, a compilation of information from Treaty Bodies, Special Procedures and UN agencies and a summary of information from civil society, both prepared by the Office of the High Commissioner

$14 \mathrm{~A} / \mathrm{HRC} / 29 / 36 ., \S 70$.

15 http://www.ohchr.org/EN/NewsEvents/Pages/DisplayNews.aspx?NewsID=16344\&LangID= E\#sthash.7Qrrj4ec.dpuf [access: 31 March 2016]. 
on Human Rights. Hence, some of the Special Procedures' recommendations addressed in the reports to the state under review are included in the compilation available for the UPR actors. It is then justified to pose the question of whether the problems highlighted by Special Procedures mandate-holders are also tackled in the UPR process. The aim of this paper is to specifically answer the question of whether the immigration problems in the EU countries are reflected in the UPR recommendations to the extent as they are in the activity of the Special Rapporteur on migrants.

The EU Member States have received 840 recommendations on migrants, asylumseekers and refugees out of the total of $2273^{16}$ (almost 40\%). Out of all the UN Member States, Italy was the recipient of the majority of the recommendations on migrants. Germany, Malta, Spain and Portugal were also among the top ten states of the list. The statistics are quite different for the EU countries as recommenders. They accounted for 316 recommendations on migrants, asylum-seekers and refugees, which is $13 \%$ of the total number. The percentage is lower when only recommendations on migrants are considered $-9 \%$. No EU Member State is among the first twenty five countries that made most of the recommendations on migrants. $28 \mathrm{EU}$ Member States constitute less than $15 \%$ of all UN Members, so this level of engagement concerning the specific issue comes as no surprise. It has to be seen, however, in light of the general involvement of the EU Member States in the UPR process ${ }^{17}$. More than $30 \%$ of all recommendations were made by EU countries, which puts the EU in the first place among the organizations whose members take up the recommendations in the UPR. In the case of many issues, the involvement of the EU countries accounts for $50 \%$ of all the submitted recommendations, e.g. torture, the death penalty, freedom of the press, freedom of association, sexual orientation and gender identity, and human rights defenders. Taking into consideration these facts, it is clear that the EU countries do not prioritize the issue of migrants. Their reluctance to raise the problems of migrants during the UPR exposes them to accusations of selectivity.

The review of Italy in the second cycle, which took place in January $2015^{18}$, is an adequate example for comparing the Special Rapporteur's conclusions with the UPR recommendations. Italy's immigration problems are widely known, so it was not surprising that a quarter of all recommendations concerned migrants, asylum-seekers and

16 All the statistics provided include the sessions up to the 20th one and they are based on the website http://www.upr-info.org [access: 31 March 2016].

17 A more detailed analysis on the EU Member States performance in the UPR is included in the Report on the analysis and critical assessment of EU engagement in UN bodies prepared in the FRAME Project funded under the European Commission's Seventh Framework Programme. The report is available on the project website: http://www.fp7-frame.eu/reports/ [access: 31 March 2016].

18 The documents of this review are available on the OHCHR website: http://www.ohchr.org/ EN/HRBodies/UPR/Pages/ITSession20.aspx [access: 31 March 2016]. 
refugees. However, it is striking that only 3 out of 49 recommendations were put forward by EU Member States. Sweden recommended that Italy suspend summary returns to Greece, which corresponds with the Special Rapporteur's recommendation to prohibit the practice of informal automatic "push-backs" to Greece ${ }^{19}$. The Netherlands addressed the issue of the training, time and ability to identify persons who want to apply for asylum, which is necessary for people involved in the reception process, and reminded that anyone claiming to be an unaccompanied minor should benefit from the specific protections guaranteed under Italian law, pending a properly conducted age determination. Denmark also referred to unaccompanied children seeking asylum, recommending that Italy introduce legislation to ensure assistance and protection for them. The other EU countries used the opportunity to address the human rights situation in Italy to deal with inter alia the ratification of international instruments, the lack of a national human rights institution, women's and LGBTI rights, and detention, whereas they did not mention the problems of migrants.

In contrast, non-EU countries paid special attention to the issue of migrants and refugees. Several examples of recommendations are worth referring to. Israel recommended that Italy develop a comprehensive national system of data collection, analysis and dissemination as regards to immigration policies and practices to be used as a foundation for rights-based policymaking on migration. It is an exact citation of the recommendation made by the Special Rapporteur on migrants after his country mis$\operatorname{sion}^{20}$. Kyrgyzstan advised that the issues of immigrant women be mainstreamed into employment policies and that undocumented migrants be allowed to protect their rights and file complaints irrespective of their immigration status. The Holy See suggested strengthening efforts in providing life-saving assistance for migrants and initiating the new Asylum, Migration and Integration Fund 2014-2020. It was also recommended that Italy e.g. conduct an active campaign against the creation of negative stereotypes in relation to migrants and minorities (by Uzbekistan), establish programmes to encourage the economic and social integration of refugees (by Mexico), improve the identification of victims of trafficking in human beings by setting up a coherent national mechanism (by Moldova), continue to give consideration to the human rights perspective in its migration policy, in collaboration with other European countries which are final destinations of migrants (by Japan), and to reactivate dialogue on migration with the North African States, namely Libya, Tunisia, Algeria, Morocco and Egypt (by South Sudan). Some recommendations concerned the ratification of the International Convention on the Protection of the Rights of All Migrant Workers and Members of Their Families. However, the silence of the EU Member States on this matter is understandable as none of them ratified the Convention. 
In the review of Malta in October $2013^{21}$ five EU Member States (Austria, France, Netherlands, Portugal and Sweden) put forward 7 out of 40 recommendations on migrants and refugees concerning the practice and the conditions of detention and the rights of children. According to these recommendations, the practice of detention of migrants should be limited and effective remedies should be provided to challenge a detention or expulsion. Additionally, it was recommended that Malta continue to address the specific needs of children, including unaccompanied minors, who should be given the benefit of the doubt until their age has been determined.

The second review of Greece took place in May 2016. In the first cycle Greece was the recipient of 10 recommendations on migrants and refugees by five EU countries (Netherlands, Poland, Slovakia, Slovenia and Sweden) ${ }^{22}$. Nine recommendations referred to the implementation of the national action plan on asylum reform and migration management. Besides that, Poland suggested that Greece ensure that no individual is directly or indirectly "refouled" to their country of origin, or any other country where they may face persecution.

The examples of Malta and Greece show greater involvement of the EU states in raising the issue of migrants than was the case with the review of Italy. The use of double standards with regard to Italy could be one explanation, but it is almost impossible to prove. The more likely reason is the reluctance of EU countries to tackle migrant problems because it is expected that other states are going to do it. Another possibility is the sense of responsibility shared by all the EU Member States who do not want their own weaknesses to be pointed out. Although these explanations seem reasonable, it is hard to accept this attitude because of its consequences. The EU Member States give the impression that they ignore the immigration problems they share and provide grounds for accusations of selectivity. This strongly influences the perception of the EU as a human rights actor by weakening its credibility.

\section{Conclusions}

The Special Rapporteur on migrants' assessment of the EU approach to immigration problems is very negative. The expert study shows that the EU Member States prioritize security over respect for human rights. This approach triggers many problems which were identified by the Special Rapporteur. The EU countries fail to protect the rights of migrants and refugees, depersonalizing them by treating as a part of the general problem of border control and security. The Special Rapporteur stated "Talking about 'flows', 'marauders', and 'swarms' is an unsubtle way of dismissing the legitimacy of the

$21 \mathrm{http} / / /$ www.ohchr.org/EN/HRBodies/UPR/Pages/MTSession17.aspx [access:31 March 2016]. 22 http://www.ohchr.org/EN/HRBodies/UPR/Pages/GRSession11.aspx [access: 31 March 2016]. 
asylum seekers and migrants' claim to human rights, by creating images linking them to toxic waste or natural disasters. (...) Migrants are human beings with rights. When we dehumanise others, we dehumanise ourselves"23. This dehumanization of certain groups constitutes a serious threat to the idea of the universality of human rights.

Immigration problems in Europe are also reflected in the Universal Periodic Review. The EU Member States receive many recommendations concerning the rights of migrants and asylum-seekers. However, they are not interested in taking up this type of recommendation. Being familiar with the difficulties faced by Italy in resolving immigration problems, most EU countries avoided raising this issue. In consequence, the objectivity of the Universal Periodic Review is contested. Moreover, the prioritisation of certain human rights in the UPR casts doubts on respecting the interdependence and indivisibility of human rights.

The burden of migrants will be impossible to control if it is not properly organised and shared between the EU Member States. In this regard, it is crucial to adopt and implement the human rights-based approach of migration policy. The EU needs to live up to its own ideals and make human rights universally available to all the people within its territory.

\section{Literature}

Council Regulation EC no. 343/2003 of 18 February 2003 establishing the criteria and mechanisms for determining the Member State responsible for examining an asylum application lodged in one of the Member States by a third-country national.

Directive 2008/115/EC of the European Parliament and of the Council of 16 December 2008 on common Standards and Procedures in Member States for Returning Illegally Staying Third-Country Nationals.

http://www.ohchr.org/EN/NewsEvents/Pages/DisplayNews.aspx?NewsID=16344\&La ngID=E\#sthash.7Qrrj4ec.dpuf [access: 31 March 2016].

http:/www.ohchr.org/EN/HRBodies/UPR/Pages/MTSession17.aspx [access: 31 March 2016]. http://www.ohchr.org/EN/HRBodies/UPR/Pages/GRSession11.aspx [access: 31 March 2016]. http://www.ohchr.org/EN/NewsEvents/Pages/DisplayNews.aspx?NewsID=16344\&La ngID=E\#sthash.7Qrrj4ec.dpuf [access: 31 March 2016].

http://www.upr-info.org [access: 31 March 2016].

23 ttp://www.ohchr.org/EN/NewsEvents/Pages/DisplayNews.aspx?NewsID=16344\&LangID= E\#sthash.7Qrrj4ec.dpuf [access: 31 March 2016]. 
86 | Adam Mickiewicz University Law Review

SUMMARY

\section{Immigration Problems Facing the European Union from the Perspective of UN Human Rights Council Mechanisms}

The scale of immigration problems in Europe today is well-known and broadly discussed. The article identifies how this issue is reflected in two Human Rights Council mechanisms: Special Procedures and the Universal Periodic Review. The Special Rapporteur on the human rights of migrants, François Crépeau, undertook a regional study on the management of the external borders of the European Union and its impact on the human rights of migrants. The analysis of the annual and country visits' reports allows the main immigration problems facing the EU countries and threats for the protection of human rights to be identified. The recommendations made by the Special Rapporteur are confronted with those taken up in the UPR process. Special attention is given to the EU countries' position on the problem of immigrants. Their reluctance to raise this issue in the UPR weakens the credibility of EU Member States and puts the objectivity of the mechanism into question.

Keywords: international protection of human rights, immigration, Universal Periodic Review, UN Special Procedures

Anna Hernandez-Połczyńska, Institute of Law Studies Polish Academy of Sciences, Nowy Świat 72,00-330 Warszawa, Republic of Poland, e-mail: anna.polczynska@inp.pan.pl. 